\title{
Mobbing and its Occurrence in the Slovak Republic
}

\section{Gabriela Sláviková - Lenka Pasternáková*}

\begin{abstract}
The paper discusses the analysis of respondents' opinions on the issue of mobbing. The authors were interested in the respondents' personal attitudes and experience thereof. Readers can find enclosed the results of the survey conducted on the discussed issue.
\end{abstract}

Key words: bullying, abuse, aggressor, causes and consequences of bullying.

Psychological terror in the workplace is a phenomenon as old as the work itself. It made its way into the public only as late as the 90s of the 20th century being viewed as the core cause of significant productivity reduction and escalation of tension and absenteeism caused by mental disorders that have been inevitably brought with it. Anglo-Saxon and Nordic countries examined and scrutinized this negative phenomenon and have labelled it as mobbing (Hirigoyenová, 2001). Mobbing includes systematic, intended and especially repeated attacks of an individual or a group at a particular person (Svobodová, 2008).

Mobbing can be discussed only if its symptoms are regularly repeated and last for a certain period of time; only then it is evident that the conflicts and misunderstandings are not of temporal nature. It is a systematic intriguing, hostile and unethical communication, often wrong behaviour and acting towards others, i.e. psychological terror in the workplace, which is initiated and managed by colleagues or superiors or subordinates and it is intended to harm, humiliate, belittle or exclude somebody from the team and by doing so to compel the person to leave the workplace (Provazník, 2002).

The conflict always works as a trigger stimulus of mobbing. Mobbing develops on the basis of a personal or work conflict which was never solved. Naturally, not every conflict evolves into mobbing. However, whether colleagues can find a reasonable solution or even more dissentions occur, that is not a matter of a pure chance. The crucial motto is the working atmosphere. Whether a person feels good at a workplace or not, primarily depends on the atmosphere in the company. Most workers feel the poor working climate as the no. 1 stress factor and they suffer from it more than they do from the pressure of time or performance (Huberová, 1995).

Another motive of mobbing can be a certain otherness of its victim; such as their hairdo, figure, clothes or different religion, but also exceptional working performances and results. In a company in which the policy of pushiness takes over and the ruthlessness is the means of climbing up the career ladder, the presence of mobbing is more presumable than in a company with open and fear-free atmosphere. Where there is no team work and the concept of team is only an empty term, workers are often fighting and plotting against each other.

Unsuitable working conditions, increased workload or ignorance of workers' needs by the management often provide fertile ground for mobbing. The triggers of mobbing are usually unbalanced persons that are driven by the fear of their own failure. Moreover, these people suffer from lowered self-esteem and mobbing is the way of improving their self-esteem condition (Gossányi, 2007). Prevention is better than cure. And just prevention is the best chance to dampen the psychological terror in a company and to stop the mobbers. There are many appropriate suggestions and proposals. To test and implement these anti-mobbing strategies is not in the competence of the affected. That is the task for unions, work councils and personal boards but particularly for the management (Huberová, 1995).

\footnotetext{
* Gabriela Sláviková, Dubnica Technological Institute, Dubnica nad Váhom, Slovakia; slavikova@dupres.sk Lenka Pasternáková, Dubnica Technological Institute, Dubnica nad Váhom, Slovakia; pasternakova@dti.sk
} 


\section{Acta Technologica Dubnicae \\ volume 2, 2012, issue 1}

Although there are no specific data available, mobbing is economically very unprofitable. With the successful mobbing prevention, absenteeism can be largely degraded. The basic preventive step is to start speaking publicly about mobbing (Provazník, 2002).

The psychological terror often finds victims totally unprepared. The basic recommendation in reaction to mobbing is always to develop the response activity in the shortest possible time. In the majority of cases, the response is possible only with the help of the others. Reactions of the affected usually differ according to their gender. Women evidently seek the assistance of others more often than men; they are far more aware of the causes and context of psychosomatic illnesses and they express themselves more openly. Men tend to downplay the psychological terror because they perceive it as a personal defeat.

There are basic rules to be kept when tackling the mobbing. The affected person must firstly answer the question whether there is a chance to reach an agreement peacefully (Provazník, 2002). If, despite all the efforts, there is no progress, it is, for the sake of personal mental health, necessary to think about handing in the notice. In such situation, it is important for the victim to keep the initiative and optimism and engage oneself in finding a job and concentrate on the future (Huberová, 1995).

If the issue of mobbing is overlooked or terminated by leaving of the victim and the mobber stays at the workplace, the whole situation may be repeated. Therefore it is important and necessary to monitor, whether new employees are hired for the same positions. It should be the role of personnel department to reveal the true state of the affairs (Svobodová, 2008).

Conflicts in work life are nothing exceptional and we are constantly surrounded by them. It takes just a problem in our private life; we meet a nervous colleague or boss and a conflict appears out of thin air. $\mathrm{He}$, who wants to survive at work, must master the conflict management. Five types of conflicts are distinguished:

- Diverting conflicts: there is a classic situation - two sides and a single problem.

- Target conflicts: two sides have different objectives.

- Role conflicts: a person is not either satisfied with or recognised in their role or the same role is claimed by several persons.

- Compliance conflicts: persons have different perspectives, cultural models, educational methods and they advocate their individual beliefs to be the only proper ones.

- Relation conflicts: persons literally cannot stand each other (Merg - Knődel, 2007).

Each long-term conflict was a quite small one once. But as it was neglected or was not taken seriously, it has grown into enormous dimensions providing strong emotions on both sides. To ignore a problem is not a solution. If we want to solve the problem quickly and reliably, we should keep several basic rules of managing the conflicts in a positive way:

- Talk about the conflict in privacy with the person directly involved. Then more people act more rationally and responsibly as in front of bystanders.

- Do not reproach but describe. When we reproach the opponent for something, we make him to defend himself. It is much safer to describe the situation from our perspective.

- Do not seek the roots, focus on solutions. Looking for the roots leads to embarrassment, reasoning and search for the culprit. Only solutions eliminate conflicts.

- Keep self-esteem and do not give way to emotions.

- Empathize to the situation of your opponent and do not try to change him.

- Agreement, not satisfaction. At the end of a discussion, it is always necessary to sum up on what we have agreed; to change the agreement into a goal and let the opponent acknowledge that he sees it so.

- Prevent future conflicts (Merg - Knődel, 2007). 


\section{Acta Technologica Dubnicae \\ volume 2, 2012, issue 1}

Each conflict should be handled immediately at its beginning; however, in some cases, any ways of mitigating the conflicts are pointless. Objectivity and self-control are the best companions and counsellors in ways how to handle the situation. Sometimes, the conflict lasts for too long; personal enmity is deep and if we really hate someone, it is impossible to find a peaceful and acceptable solution in a discussion. Then it is good to take a few days off in order to calm down and relax. Moreover, people facing this situation should seek professional help because mobbing is an enormous psychological stress. Sometimes, however, there is the only solution: to change the job (Benešovská, 2009).

Each of us faced crisis and stressful situation at work, which we tried to solve, either successfully or unsuccessfully. Stress at workplace can be caused by various factors. Among the major stress factors are fear of losing the job, increased job demands, disturbed interpersonal relationships, and conflicts with supervisor. Long-term exposure of a worker to one or more stressors can be the cause of several health problems.

It is not possible to prevent stress in the workplace, but there are ways how to manage it:

- invest into interpersonal relationship - attentiveness to others, respect, willingness to listen to them, understanding them, praising them and remembering, for instance, their birthday but also paying the attention to their criticism or learning to establish a compromise helps to eliminate stress and prevents other stress factors (Praško, 2007);

- follow the principles of efficient communication - efficiency of a correct communication depends on the ability to understand verbal and non-verbal messages around you; it is necessary to pay attention to gestures, voice tone and role of your colleagues;

- choose the right job - at the job interview, ask questions in order to achieve a real picture of the company and department, work culture, interpersonal relationships and potential or hidden problems;

- control potential anger - if you feel your nervousness rise, leave the environment as fast as possible and try to breathe deeply; identify the real source of your anger and make a communication plan in order to communicate with people with whom you are in conflict; this will prevent displaying unexpected emotions;

- have realistic expectations - if you want to avoid disappointment, do not overdo your future success vision; always check on the real chances for reaching the set result and correct your expectations accordingly;

- adjust your attitudes - your attitudes affect the way people perceive you and the way your surroundings perceives themselves in your presence; try to see the world through the eyes of other people; does your presence raise good or bad feelings?; if you are not satisfied with what you see, you may need to change your attitudes;

- follow through with things - disability to follow things through to an end can may become a burden in the future; to fulfill something means to reach an inner feeling of satisfaction for all involved parties; therefore remember to provide evaluation, feedback and praise; if you are assigned a new task and you have not finished the previous one, make a list of "to do" tasks;

- treat yourself a holiday - people are not machines and therefore they cannot work without a break till total wear; people need to relax; if possible, avoid taking work home with you.

According to the experts, the causes of mobbing lie also in the attitudes and behaviour of managers. Therefore, managers should, therefore, not ignore mobbing. Each boss should be familiar with, at least, basics of psychology and attend several practical courses and trainings in order to learn something about conflicts and communication problems and their management. They should try to learn as much about their subordinates as possible - to know, what is important for them, what they wish for and what they have done. Those, who are attentive, consistent and observant enough, can reveal possible traces of conflicts. Bosses are responsible for ensuring that their subordinates have 


\section{Acta Technologica Dubnicae \\ volume 2, 2012, issue 1}

done their best and in the best possible conditions. If any of them comes in need of help with a problem, a boss should pay the attention. Company should, in any case, take mobbing seriously and properly examine the situation. They cannot stay impartial in the case of mobbing, be it of moral or economic reasons. They must take appropriate measures to make clear that mobbing is unwanted in the company (Kratz, 2005).

Mobbing prevention in the company may include training of workers in charge of dealing with the issue of mobbing. It includes especially legal education and assertive behaviour trainings in order to learn to judge by themselves the seriousness of their behaviour and to develop adequate response to various stimuli or to divert them away. Hence, it is important to teach the workers specific principles of mental hygiene so that they will increase their resistance to stressful situations (Horváth, 2001).

The management style reflects the way of the intended and planned influence on workers and their performance so the company is able to meet its objectives. The management style describes forms of communication between superiors and subordinates. Authoritative management style anticipates a boss with ultimate competencies providing all the necessary decisions on his own. Subordinates are obliged to carry out his decisions in a perfect and infallible manner; they are permanently controlled. This management style can be drastically manifested in company's turnover, which can reach up to $100 \%$.

A counterpart of the previous management style is a cooperative management style. Boss perceives the subordinates as colleagues and partners who, according to their skills, knowledge and experience, actively participate in the process of achieving the set objectives. Thus, delegation of tasks, powers and responsibilities allows the workers considerable amount of autonomy. The company is managed by the spirit of partnership, free of pressure, pushiness and unhealthy desire for power (Kratz, 2005).

Information and education should focus on the issue of mobbing at all corporate levels. That could be provided during meetings or via anti-mobbing campaigns (Kratz, 2005). Prevention is better than therapy and therefore various forms of seminars and trainings for not only executives but all employees are proposed. In these sessions, information on causes and impacts of mobbing is spread and various conflict solution models are discussed. It should be clearly stated, what is an appropriate behaviour and what is not. Each worker should know what mobbing is and how it can endanger the atmosphere in the company, performance of workers and its negative impact on human health.

Many experts require companies to designate one person, who will, analogically to an ill person, take care of all problems that have been caused by psychological terror. The body might be a corporate council or a generally recognised colleague who has been especially trained for such situation or it also might be an impartial professional.

It is especially in the large enterprises where the stress and deadline pressure rule the team and so the exchange of views between colleagues is frequent. There is a quick group formation and raise of various misunderstandings. A possible solution is to have a monthly meeting of a department or a team in which subordinates and superiors can equally express their opinions on the subject matter. The topic of such session is the present situation and search for the roots of problems. It is a handy tool of handling the conflicts and erasing minor misunderstandings between colleagues (Huberová, 1995).

We cannot find specific references in our legislation referring to the solution of psychological terror, bullying or sexual harassment in the workplace. NR SR Act No. 311/2001 Coll. Labour Code, as amended, provides in its Basic principles as well as in $\$ 13$ prohibition of discrimination, i.e. the right to work without restrictions and direct or indirect discrimination. And it declares that the execution of rights and obligations arising from the labour relations must be conducted with regard to good manners. No one shall abuse these rights and obligations to the detriment of the other. No one shall demean the dignity of workers at workplace. Employees who suffered the damage resulting from a breach of labour relations can claim their rights in court. 


\section{Acta Technologica Dubnicae \\ volume 2, 2012, issue 1}

NR SR Act No. 124/2006 Coll. On safety and health at work as amended, states that employer must ensure that the factors affecting mental workload and social factors do not endanger safety and health of employees. Description and recognition of the forms of aggression helps us to achieve an early awareness of danger and provides us with the possibility to eliminate identified risks effectively.

It is important to identify exactly what shall be recognized as mobbing at workplace and what shall be not. The definition should be implemented, for instance, into the Labour Code. Authorities competent for dealing with the mobbing at workplace should be designated and these should, in cooperation with employees, deliver a detailed strategy drafted in accordance with established criteria. Thus, the jointly prepared procedure should be, and currently is, mandatory for all workers and its effectiveness is subjected to the consent of trade union bodies (in accordance with $\S 82$, par. 3 LC).

Legislative measures could include sanctions and responsibilities of solutions of specific causes and administrations of legal remedies (appeals). In regard to the gravity, the cases would be addressed either disciplinary at the workplace or by a legal action. Administrative measures could include where and how workers can lodge their complaints, their records and assessments of further procedure. Counselling could be also a part of these measures. The complaint should remain anonymous till the start or even during the investigation, if the case requires so (Horváth, 2001)

In the context of the issue of mobbing, we conducted a survey which aimed to identify and analyse current situation in working climate of teams and employees' experiences of mobbing in private companies in Slovakia. Based on this objective we have set the following survey tasks:

1. Identify groups that participated in the survey by demographic data.

2. Determine whether mobbing occurs in private companies in Slovakia and asses its scope.

3. Identify the role of mobbed workers.

4. Determine to what extent the experience is individual or collective.

5. Analyse the average occurrence of negative acts and their frequency.

6. Characterize the person who committed the negative acts in a acollective on the basis of the evaluation sheet.

To conduct the survey, we used the questionnaire method. The reason why we decided to use the questionnaire was the fact that this method allowed us to obtain a considerable amount of information in a short period of time. We also considered its disadvantage that some employees might not fill in all the items and some employees might not have completed the questionnaire at all due to the fear of losing their job even though the questionnaire was anonymous.

Formulation of items in the questionnaire was provided with regard to three sets of data. The first set consisted of items focused on the demographic data. The second set consisted of specific questions detecting personal experiences of employees with negative acts. The third set detected feelings of employees about the person who committed the negative acts through twelve character traits that the person manifests.

Respondents were employees of private companies in Slovakia, working at various department and positions. The questionnaires were distributed by supervisors who were also in charge to collect them back. The total amount of distributed questionnaires was 150. The total amount of participants was $127(85 \%)$, that is, with regard to the sensitive issue of survey, rather high return. The survey was conducted in spring 2011 and the obtained information was interpreted in quantitative and in qualitative analysis.

The aim of the first set of items was to identify the groups that participated in the survey. We identified the respondents by their gender, age group, marital status and education, position in the company and the number of subordinates. 


\begin{tabular}{||l|c|c|c|c|c|c||}
\hline \multirow{2}{*}{ Age categories } & \multicolumn{2}{|c|}{ Men } & \multicolumn{2}{c|}{ Women } & \multicolumn{2}{c||}{ Total } \\
\cline { 2 - 7 } & $\mathbf{N}$ & $\boldsymbol{\%}$ & $\mathbf{N}$ & $\boldsymbol{\%}$ & $\mathbf{N}$ & $\boldsymbol{\%}$ \\
\hline $\mathbf{2 0 - 3 0}$ & 5 & $6 \%$ & 1 & $2 \%$ & 6 & $5 \%$ \\
\hline $\mathbf{3 1 - 4 0}$ & 25 & $29 \%$ & 10 & $24 \%$ & 35 & $28 \%$ \\
\hline $\mathbf{4 1 - 5 0}$ & 38 & $45 \%$ & 19 & $45 \%$ & 57 & $45 \%$ \\
\hline $\mathbf{5 1 - 6 0}$ & 17 & $20 \%$ & 12 & $29 \%$ & 29 & $23 \%$ \\
\hline Total & 85 & $100 \%$ & 42 & $100 \%$ & 127 & $100 \%$ \\
\hline \hline
\end{tabular}

Table 1 Composition of survey sample by age and sex

The total number of respondents participating in the survey (127) the survey involved 85 men (67\%) and 42 women (33\%). The most numerous group consisted of men in the age group of 41-50 years $31(45 \%)$ and women dominated in the age group of $41-50$ years $-19(45 \%)$. Numerically the lowest sample in men and women was the age category of 20-30 years - men $5(6 \%)$ and women $1(2 \%)$. The overall average age of all participants was 44 years; with men the average age was 43 years, with women 45 years. It is the middle adult period and the period of the highest working ability and the highest performance.

\begin{tabular}{||l|c|c|c|c|c|c||}
\hline \multirow{2}{*}{ Marital status } & \multicolumn{2}{|c|}{ Men } & \multicolumn{2}{|c|}{ Women } & \multicolumn{2}{c|}{ Total } \\
\cline { 2 - 7 } & $\mathrm{N}$ & $\mathbf{\%}$ & $\mathbf{N}$ & $\mathbf{\%}$ & $\mathbf{N}$ & $\%$ \\
\hline Married & 62 & $73 \%$ & 33 & $79 \%$ & 95 & $75 \%$ \\
\hline Divorced & 4 & $5 \%$ & 3 & $7 \%$ & 7 & $6 \%$ \\
\hline Widow/Widower & 2 & $2 \%$ & 0 & $0 \%$ & 2 & $2 \%$ \\
\hline Single & 17 & $20 \%$ & 6 & $14 \%$ & 23 & $18 \%$ \\
\hline Total & 85 & $100 \%$ & 42 & $100 \%$ & 127 & $100 \%$ \\
\hline
\end{tabular}

Table 2 Marital status of respondents

As we have anticipated, the prevailing marital status of men as well as women is married; men 62 (73\%), women 33 (79\%). Numerically the smallest group of men and in women are widows/widowers: 2 are men (2\%) and 0 women $(0 \%)$.

\begin{tabular}{||l|c|c|c|c|c|c||}
\hline \multirow{2}{*}{ Education } & \multicolumn{2}{|c|}{ Men } & \multicolumn{2}{c|}{ Women } & \multicolumn{2}{c||}{ Total } \\
\cline { 2 - 7 } & $\mathbf{N}$ & $\%$ & N & $\%$ & N & $\%$ \\
\hline Primary & 3 & $4 \%$ & 0 & $0 \%$ & 3 & $2 \%$ \\
\hline $\begin{array}{l}\text { Secondary without } \\
\text { GRE }\end{array}$ & 17 & $20 \%$ & 5 & $12 \%$ & 22 & $17 \%$ \\
\hline Secondary with GRE & 52 & $61 \%$ & 28 & $67 \%$ & 80 & $63 \%$ \\
\hline University & 13 & $15 \%$ & 9 & $21 \%$ & 22 & $17 \%$ \\
\hline Total & 85 & $100 \%$ & 42 & $100 \%$ & 127 & $100 \%$ \\
\hline \hline
\end{tabular}

Table 3 Education of respondents 


\section{Acta Technologica Dubnicae \\ volume 2, 2012, issue 1}

Most respondents are secondary school graduates with GRE, 52 (61\%) men and 28 (67\%) women. Minimum of participants are only primary school graduates, $3(4 \%)$ men, $0(0 \%)$ women, which shows that the companies realize the importance to employ qualified people and that the improvement of workforce skills is among their essential goals. $22(17 \%)$ respondents are university graduates; 13 (15\%) men and $9(21 \%)$ women.

\begin{tabular}{||l|c|c|c|c|c|c||}
\hline \multirow{2}{*}{\multicolumn{1}{|c|}{ Position }} & \multicolumn{2}{|c|}{ Men } & \multicolumn{2}{c|}{ Women } & \multicolumn{2}{c||}{ Total } \\
\cline { 2 - 7 } & $\mathbf{N}$ & $\boldsymbol{\%}$ & $\mathbf{N}$ & $\boldsymbol{\%}$ & $\mathbf{N}$ & $\%$ \\
\hline Employee & 71 & $84 \%$ & 37 & $88 \%$ & 108 & $85 \%$ \\
\hline Middle management & 13 & $15 \%$ & 5 & $12 \%$ & 18 & $14 \%$ \\
\hline Senior management & 1 & $1 \%$ & 0 & $0 \%$ & 1 & $1 \%$ \\
\hline Other & 0 & $0 \%$ & 0 & $0 \%$ & 0 & $0 \%$ \\
\hline Total & 85 & $100 \%$ & 42 & $100 \%$ & 127 & $100 \%$ \\
\hline
\end{tabular}

Table 4 Position in a company

This item should identify the respondents' position in the company, which may be a crucial factor influencing mobbing. Both men and women formed the largest group of employees in total of 108 $(85 \%) ; 71(84 \%)$ men, $37(88 \%)$ women, and on the contrary, the smallest group of respondents belonged to the senior management - very small number of just $1(1 \%)$ man. 18 respondents worked in middle management (14\%); $13(15 \%)$ men and $5(12 \%)$ women.

\begin{tabular}{||c|c|c|c|c|c|c||}
\hline \multirow{2}{*}{ Executive } & \multicolumn{2}{|c|}{ Men } & \multicolumn{2}{|c|}{ Women } & \multicolumn{2}{c|}{ Total } \\
\cline { 2 - 7 } & $\mathbf{N}$ & $\mathbf{\%}$ & $\mathbf{N}$ & $\mathbf{\%}$ & $\mathbf{N}$ & $\mathbf{\%}$ \\
\hline Yes & 14 & $16 \%$ & 4 & $10 \%$ & 18 & $14 \%$ \\
\hline No & 71 & $84 \%$ & 38 & $90 \%$ & 109 & $86 \%$ \\
\hline Total & 85 & $100 \%$ & 42 & $100 \%$ & 127 & $100 \%$ \\
\hline \hline
\end{tabular}

Table 5 Number of executives

$18(14 \%)$ are executives out of all the 127 respondents; this makes 14 (16\%) men, 4 (10\%) women. Most respondents - 109 (86\%), 71 (84\%) men and 38 (90\%) women, are not executives.

The aim of the second set of items was to identify personal experience with mobbing directly as a victim or indirectly, as a witness of it. The detection was carried out via questions identifying specific negative acts. The items of the questionnaire were divided into two sections. In the first section, we identified personal experience with mobbing and frequency of occurrence of negative acts at a workplace. When answering each questions, respondents could choose a five-digit range of intensity ( 1 - never, 2 - from time to time, 3 - once in a month, 4 - once in a week, 5 - daily), which expressed the frequency of negative acts occurrence. The following tables show the incidence and frequency of negative acts described in the questionnaire. 


\begin{tabular}{||l|c|c|c|c|c|c||}
\hline \hline & Men & Men & Women & Women & Total & Total \\
\cline { 2 - 7 } & $\mathbf{N}$ & $\%$ & $\mathbf{N}$ & $\%$ & $\mathbf{N}$ & $\%$ \\
\hline Never any act & 10 & $12 \%$ & 8 & $19 \%$ & 18 & $14 \%$ \\
\hline $\begin{array}{l}\text { At least sometimes with } \\
\text { some }\end{array}$ & 75 & $88 \%$ & 34 & $81 \%$ & 109 & $86 \%$ \\
\hline & 85 & $100 \%$ & 42 & $100 \%$ & 127 & $100 \%$ \\
\hline
\end{tabular}

Table 6 Never experienced a negative act

Based on the responses of the 127 respondents, 18 (14\%) employees have never experienced negative acts; $10(12 \%)$ of them were men and $8(19 \%)$ were women. Most respondents $109(86 \%)$ have experienced some negative acts from time to time. Slandering, monitoring, verbal harassment, criticizing and deliberate withholding of information are common practices. It is necessary to realize that if the colleagues or superiors refuse and humiliate the victim, his/her time at work becomes unbearable and it reduces his/her concentration on performance and increases the probability of errors which creates an opportunity for repetition and escalation of negative acts. Damage to the victim's health and, if it is a good employee, handing in the notice, are hardly recoverable losses for the company.

Table 7 and Table 8 show the average incidence and frequency of negative acts.

\begin{tabular}{|c|c|c|c|c|c|c|c|c|c|c|c|c|}
\hline & \multicolumn{2}{|c|}{ Never } & \multicolumn{2}{|c|}{ Sometimes } & \multicolumn{2}{|c|}{ Monthly } & \multicolumn{2}{|c|}{ Weekly } & \multicolumn{2}{|c|}{ Daily } & \multicolumn{2}{|c|}{ Mobbed total } \\
\hline & $\mathbf{N}$ & $\%$ & $\mathbf{N}$ & $\%$ & $\mathbf{N}$ & $\%$ & $\mathbf{N}$ & $\%$ & $\mathbf{N}$ & $\%$ & $\mathbf{N}$ & $\%$ \\
\hline Men & 60.8 & $71.6 \%$ & 19.8 & $23.3 \%$ & 3.0 & $3.6 \%$ & 0.9 & $1.1 \%$ & 0.4 & $0.4 \%$ & 24.2 & $28.4 \%$ \\
\hline Women & 30.5 & $72.6 \%$ & 10.5 & $25.0 \%$ & 0.6 & $1.5 \%$ & 0.3 & $0.7 \%$ & 0.1 & $0.3 \%$ & 11.5 & $27.4 \%$ \\
\hline Total & 91.3 & $71.9 \%$ & 30.3 & $23.9 \%$ & 3.7 & $2.9 \%$ & 1.2 & $1.0 \%$ & 0.5 & $0.4 \%$ & 35.7 & $28.1 \%$ \\
\hline
\end{tabular}

Table 7 Experience with negative acts occurrence

Out of the 29 negative acts in average, the respondents said that in $71.9 \%$ they have never experienced negative acts; $23.9 \%$ have sometimes experienced negative acts; $2.9 \%$ monthly; $1 \%$ weekly and $0.4 \%$ are experiencing any of the stated negative acts on a daily basis. With regard to personal experience with a negative act, it is not only one-time experience but recurring unpleasant events. The most commonly experienced negative acts in the last six months according to the questionnaire were the following:

Men:

1. Ignorance of my views and opinions $56 \%$ (act no.16).

2. Spreading rumours and gossip about me $56 \%$ (act no. 6).

3. Assigning the tasks below my qualification and skills 53\% (act no. 4).

4. Withholding the information necessary for fulfillment of your tasks $51 \%$ (act no.1).

5. Constant work criticism $40 \%$ (act no. 15).

6. Recurring reminding of my mistakes and errors $39 \%$ (act no. 13).

7. Attempts to find errors in your work $38 \%$ (act no. 27).

8. Hoax $36 \%$ (act no. 18 ).

9. Profanities and spontaneous expressions of anger $34 \%$ (act no. 9).

10. Withdrawing some of my duties $33 \%$ (act no. 5). 


\section{Acta Technologica Dubnicae \\ volume 2, 2012, issue 1}

11. Offensive remarks about me and my personal life 33\% (act no. 8).

12. Exaggerated jokes, making fun of me, sarcasm $33 \%$ (act no. 25).

Women:

1. Spreading rumours and gossip about me $71 \%$ (act no. 6).

2. Ignorance of my views and opinions $50 \%$ (act no. 16).

3. Withholding the information necessary for fulfillment of my tasks $50 \%$ (act no. 1).

4. Recurring reminding of my mistakes and errors $40 \%$ (act no. 13).

5. Attempts to find errors in my work $40 \%$ (act no. 27).

6. Constant criticism of my work and efforts $38 \%$ (act no. 15).

7. Excessive monitoring of my work $36 \%$ (act no. 22 ).

8. Delegation of tasks with unrealizable objectives $33 \%$ (act no. 20).

9. Exposure to unmanageable workload $29 \%$ (act no. 28).

10. Exaggerated jokes, making fun of me, sarcasm $26 \%$ (act no. 25).

11. Private messenger $26 \%$ (act no. 19).

In the second part of the questionnaire items we indentified whether these negative acts were perceived as mobbing, their topicality, who committed them and how many employees in the past five years, respectively, in six months were victims or witnesses of mobbing in their surroundings.

\begin{tabular}{|c|c|c|c|c|c|c|c|}
\hline \multirow{2}{*}{$\begin{array}{l}\text { Have you been a } \\
\text { victim of mobbing } \\
\text { in the past } 6 \\
\text { months? }\end{array}$} & 1 & 2 & 3 & 4 & 5 & 6 & \\
\hline & $\begin{array}{c}\text { No } \\
\text { never }\end{array}$ & $\begin{array}{l}\text { Only } \\
\text { rarely }\end{array}$ & $\begin{array}{l}\text { Sometimes, } \\
\text { from time } \\
\text { to time }\end{array}$ & $\begin{array}{c}\text { Several } \\
\text { times a } \\
\text { month }\end{array}$ & $\begin{array}{c}\text { Several } \\
\text { times a } \\
\text { week }\end{array}$ & Daily & $\begin{array}{c}\text { Total } \\
\text { Mobbed }\end{array}$ \\
\hline \multirow[t]{2}{*}{ Men } & 74 & 5 & 5 & 1 & 0 & 0 & 11 \\
\hline & $87 \%$ & $6 \%$ & $6 \%$ & $1 \%$ & $0 \%$ & $0 \%$ & $13 \%$ \\
\hline \multirow[t]{2}{*}{ Women } & 39 & 2 & 1 & 0 & 0 & 0 & 3 \\
\hline & $93 \%$ & $5 \%$ & $2 \%$ & $0 \%$ & $0 \%$ & $0 \%$ & $7 \%$ \\
\hline \multirow[t]{2}{*}{ Total } & 113 & 7 & 6 & 1 & 0 & 0 & 14 \\
\hline & $89 \%$ & $6 \%$ & $5 \%$ & $1 \%$ & $0 \%$ & $0 \%$ & $11 \%$ \\
\hline
\end{tabular}

Table 8 Mobbing victims in past six months

Out of the 127 respondents $14(11 \%)$ perceived negative acts such as mobbing, including 11 men (13\%) and 3 women (7\%). $6 \%$ of respondents said that they had been mobbed only rarely; 5\% sometimes and $1 \%$ monthly. Mobbing has not occurred in higher frequency, i.e. weekly.

\begin{tabular}{||c|c|c|c|c||}
\hline \multirow{3}{*}{ Men } & $(\mathbf{1})$ & $\mathbf{( 2 + 3 + 4 )}$ & $\mathbf{( 5 + 6 )}$ & $\mathbf{( 2 + 3 + 4 + 5 + 6 )}$ \\
\cline { 2 - 5 } & \multirow{2}{*}{ No never } & Occasionally & Regularly & Total mobbed \\
\hline \multirow{2}{*}{ Women } & 74 & 11 & 0 & 11 \\
\cline { 2 - 5 } & $87.1 \%$ & $12.9 \%$ & $0.0 \%$ & $12.9 \%$ \\
\cline { 2 - 5 } & 39 & 3 & 0 & 3 \\
\hline \multirow{2}{*}{ Total } & $92.9 \%$ & $7.1 \%$ & $0.0 \%$ & 14 \\
\cline { 2 - 5 } & $89.0 \%$ & 113 & $0.0 \%$ & $11.0 \%$ \\
\hline
\end{tabular}

Table 9 Mobbing occurrence 


\section{Acta Technologica Dubnicae \\ volume 2, 2012, issue 1}

We combined the frequency categories (Table 8) and created three frequency categories: not mobbed, occasionally mobbed and regularly mobbed. In percentage terms, it reads $11 \%$ out of overall respondents were mobbed occasionally, 11 men (12.9\%) and 3 women (7.1\%). None of the respondents is mobbed regularly, which is a positive indication, $89 \%$ of respondents do not perceive negative acts as mobbing because their frequency is very rare and so in this case, we are not dealing with mobbing because, according to Leyman's definition of mobbing, it is considered to be executed only if a person is attacked once a week for six months minimum by one or more persons. In the following evaluation we tried to determine the position of the mobbed within the company; we monitored the influence of position on the perception of mobbing.

\begin{tabular}{|c|c|c|c|c|c|c|c|}
\hline & $30(1)$ & $30(2-6)$ & $30(2+3+4)$ & $30(5+6)$ & 36 (a) & 37 (b) \\
\hline & & No never & $\begin{array}{c}\text { Total } \\
\text { mobbed in } \\
\text { last } 6 \\
\text { months }\end{array}$ & Occasionally & Regularly & $\begin{array}{c}\text { Total } \\
\text { mobbed in } \\
\text { last } 5 \text { years }\end{array}$ & $\begin{array}{c}\text { Witnesses } \\
\text { of mobbing } \\
\text { in last } 5 \\
\text { years }\end{array}$ \\
\hline \multirow{2}{*}{ Employees } & 105 & 93 & 12 & 12 & 0 & 15 & 26 \\
\hline & & $89 \%$ & $11 \%$ & $11 \%$ & $0 \%$ & $14 \%$ & $25 \%$ \\
\hline \multirow{2}{*}{ Executives } & 18 & 16 & 2 & 2 & 0 & 3 & 4 \\
\hline & & $89 \%$ & $11 \%$ & $11 \%$ & $0 \%$ & $17 \%$ & $22 \%$ \\
\hline \multirow{2}{*}{$\begin{array}{c}\text { Middle } \\
\text { management }\end{array}$} & 18 & 16 & 2 & 2 & 0 & 3 & 3 \\
\hline & & $89 \%$ & $11 \%$ & $11 \%$ & $0 \%$ & $17 \%$ & $17 \%$ \\
\hline \multirow{2}{*}{$\begin{array}{c}\text { Senior } \\
\text { management }\end{array}$} & 1 & 1 & 0 & 0 & 0 & 0 & 1 \\
\hline & & $100 \%$ & $0 \%$ & $0 \%$ & $0 \%$ & $0 \%$ & $100 \%$ \\
\hline
\end{tabular}

Table 10 Influence of position on mobbing

Out of the total of 14 victims in last 6 months most - $12(11 \%)$ - are ordinary employees and $2(11 \%)$ are in the senior management group. A positive finding is that none of the mobbed experienced mobbing on the regular basis.

The facts that 14 respondents admitted that they had been mobbed during past 6 months and a number of victims increased to 18 in last 5 years indicate that mobbing cannot be considered as a secondary social problem anymore. This is also confirmed by the number of witnesses of mobbing in past 5 years, that is, the total of 30 ( 22 men and 8 women), which is nearly one quarter $-24 \%$. Witnesses, by standing idly by, help the mobber to commit the negative offences continually and become the socalled accomplices of mobbing. 16 people were both witnesses and victims of mobbing, 11 men and 5 women. According to this result, the number of witnesses that were also victims is higher in comparison to those who were not mobbed at all. It is clear that those respondents are more sensitive to the working climate and they are more attentive to their surroundings.

\begin{tabular}{||c|c|c|c|c|c|c||}
\hline \hline \multirow{2}{*}{ Persons who mobbed } & \multicolumn{2}{|c|}{ Men } & \multicolumn{2}{c|}{ Women } & \multicolumn{2}{c||}{ Total } \\
\cline { 2 - 7 } & $\mathbf{N}$ & $\boldsymbol{\%}$ & $\mathbf{N}$ & $\mathbf{\%}$ & $\mathbf{N}$ & $\%$ \\
\hline Colleague $-\boldsymbol{h e}$ & 4 & $25 \%$ & 1 & $33 \%$ & 5 & $26 \%$ \\
\hline Colleague - she & 0 & $0 \%$ & 1 & $33 \%$ & 1 & $5 \%$ \\
\hline Group of male colleagues & 0 & $0 \%$ & 0 & $0 \%$ & 0 & $0 \%$ \\
\hline Group of female colleagues & 0 & $0 \%$ & 0 & $0 \%$ & 0 & $0 \%$ \\
\hline Mixed group & 3 & $19 \%$ & 0 & $0 \%$ & 3 & $16 \%$ \\
\hline Subordinate & 2 & $13 \%$ & 0 & $0 \%$ & 2 & $11 \%$ \\
\hline Superior & 7 & $44 \%$ & 1 & $33 \%$ & 8 & $42 \%$ \\
\hline Total & 16 & $100 \%$ & 3 & $100 \%$ & 19 & $100 \%$ \\
\hline
\end{tabular}

Table 11 Who mobbed 


\section{Acta Technologica Dubnicae \\ volume 2, 2012, issue 1}

In the questionnaire we were interested in detecting the number of mobbers and those who mobbed. Men were mobbed by their superiors (bossing) in 44\%, in 25\% only one person was an aggressor against a single individual, in $19 \%$ mobbing was committed by a mixed group against a single individual, and in $13 \%$ a superior was mobbed by a subordinate (staffing). With women, $42 \%$ of mobbing was committed by the superiors against subordinates (bossing), in 5\% the aggressor was a woman - a female colleague, and an interesting finding is that in $26 \%$ the aggressors were men; the group of mobbers against a single individual did not occur with women.

In the last third set of items, the respondents' task was to characterize the traits of a person who committed negative acts defined in the evaluation sheet. The sheet consisted of 12 personal traits. The evaluation scale consisted of four grades with a trait (value 1), its counterpoint (value 4) and two intermediates (value 2 and 3). 41 respondents completed this evaluation sheet, 27 men and 14 women.

Based on the survey of mobbers' personal traits and their evaluation, we can conclude the following: the perpetrator of negative acts is rather psychosomatically disturbed, irritable, rather aggressive and depressive, less calm, more sociable, lively, well-minded, slightly dominant, rather tensed, open, critical, extrovert, emotionally stable with typical male characteristics.

The provided evaluation of the traits cannot be considered accurate and authoritative because it is generally difficult to clearly identify the character of a mobber. However, it is possible to structure fundamental thinking of a mobber, that is, the basis of his thinking is an effort to find something negative about the victim, even if the victim is an absolutely perfect, flawless and ideal person, because the mobber does not hesitate to use almost any means available, even those immoral ones. It is important to realize that a person, who needs to build his own self confidence by humiliating and harming others, is weak and probably suffers from a complex.

\begin{tabular}{|c|c|c|c|c|c|c|c|c|c|c|c|c|}
\hline Category & \multicolumn{4}{|c|}{ Total } & \multicolumn{4}{|c|}{ Men } & \multicolumn{4}{|c|}{ Women } \\
\hline Trait & $\begin{array}{l}1 \\
\mathbf{N}\end{array}$ & $\begin{array}{c}2 \\
\mathbf{N}\end{array}$ & $\begin{array}{c}3 \\
\mathbf{N}\end{array}$ & $\begin{array}{c}4 \\
N\end{array}$ & $\begin{array}{l}1 \\
\mathbf{N}\end{array}$ & $\begin{array}{c}2 \\
\mathbf{N}\end{array}$ & $\begin{array}{c}3 \\
\mathbf{N}\end{array}$ & $\begin{array}{c}4 \\
N\end{array}$ & $\begin{array}{c}\mathbf{1} \\
\mathbf{N}\end{array}$ & $\begin{array}{c}2 \\
\mathbf{N}\end{array}$ & $\begin{array}{c}3 \\
\mathbf{N}\end{array}$ & $\begin{array}{l}4 \\
\mathbf{N}\end{array}$ \\
\hline 1 - Nervousness & 4 & 11 & 21 & 6 & 1 & 9 & 13 & 4 & 3 & 2 & 8 & 2 \\
\hline 2 - Aggression & 4 & 9 & 26 & 3 & 2 & 8 & 15 & 2 & 2 & 1 & 11 & 1 \\
\hline 3 - Depression & 6 & 15 & 20 & 1 & 1 & 11 & 14 & 1 & 5 & 4 & 6 & 0 \\
\hline 4 - Irritability & 2 & 19 & 18 & 3 & 1 & 11 & 13 & 2 & 1 & 8 & 5 & 1 \\
\hline 5 - Sociability & 8 & 16 & 12 & 5 & 5 & 11 & 8 & 2 & 3 & 5 & 4 & 3 \\
\hline 6 - Gentleness & 7 & 19 & 11 & 4 & 6 & 12 & 7 & 1 & 1 & 7 & 4 & 3 \\
\hline 7 - Dominance & 4 & 9 & 18 & 10 & 3 & 7 & 10 & 6 & 1 & 2 & 8 & 4 \\
\hline 8 - Continence & 9 & 21 & 10 & 1 & 5 & 11 & 10 & 0 & 4 & 10 & 0 & 1 \\
\hline 9 - Openness & 12 & 16 & 10 & 3 & 5 & 13 & 6 & 2 & 7 & 3 & 4 & 1 \\
\hline 10 - Extroversion & 7 & 16 & 15 & 3 & 2 & 13 & 10 & 1 & 5 & 3 & 5 & 2 \\
\hline \begin{tabular}{|c|}
11 - Emotional \\
instability
\end{tabular} & 5 & 12 & 20 & 4 & 3 & 10 & 13 & 0 & 2 & 2 & 7 & 4 \\
\hline 12-Masculinity & 4 & 25 & 9 & 3 & 3 & 14 & 7 & 2 & 1 & 11 & 2 & 1 \\
\hline
\end{tabular}

Table 14 Traits of a mobber-numerical evaluation 


\begin{tabular}{|c|c|c|c|c|c|c|c|c|c|c|c|c|}
\hline Category & \multicolumn{4}{|c|}{ Total } & \multicolumn{4}{|c|}{ Men } & \multicolumn{4}{|c|}{ women } \\
\hline Trait & $1 \%$ & $2 \%$ & $3 \%$ & $4 \%$ & $1 \%$ & $2 \%$ & $3 \%$ & $4 \%$ & $1 \%$ & $2 \%$ & $3 \%$ & $4 \%$ \\
\hline 1 - Nervousness & $9.5 \%$ & $26.2 \%$ & $50.0 \%$ & $14.3 \%$ & $3.7 \%$ & $33.3 \%$ & $48.1 \%$ & $14.8 \%$ & $20.0 \%$ & $13.3 \%$ & $53.3 \%$ & $13.3 \%$ \\
\hline 2 - Aggression & $9.5 \%$ & $21.4 \%$ & $61.9 \%$ & $7.1 \%$ & $7.4 \%$ & $29.6 \%$ & $55.6 \%$ & $7.4 \%$ & $13.3 \%$ & $6.7 \%$ & $73.3 \%$ & $6.7 \%$ \\
\hline 3 - Depression & $14.3 \%$ & $35.7 \%$ & $47.6 \%$ & $2.4 \%$ & $3.7 \%$ & $40.7 \%$ & $51.9 \%$ & $3.7 \%$ & $33.3 \%$ & $26.7 \%$ & $40.0 \%$ & $0.0 \%$ \\
\hline 4 - Irritability & $4.8 \%$ & $45.2 \%$ & $42.9 \%$ & $7.1 \%$ & $3.7 \%$ & $40.7 \%$ & $48.1 \%$ & $7.4 \%$ & $6.7 \%$ & $53.3 \%$ & $33.3 \%$ & $6.7 \%$ \\
\hline 5 - Sociability & $19.5 \%$ & $39.0 \%$ & $29.3 \%$ & $12.2 \%$ & $19.2 \%$ & $42.3 \%$ & $30.8 \%$ & $7.7 \%$ & $20.0 \%$ & $33.3 \%$ & $26.7 \%$ & $20.0 \%$ \\
\hline 6 - Gentleness & $17.1 \%$ & $46.3 \%$ & $26.8 \%$ & $9.8 \%$ & $23.1 \%$ & $46.2 \%$ & $26.9 \%$ & $3.8 \%$ & $6.7 \%$ & $46.7 \%$ & $26.7 \%$ & $20.0 \%$ \\
\hline 7 - Dominance & $9.8 \%$ & $22.0 \%$ & $43.9 \%$ & $24.4 \%$ & $11.5 \%$ & $26.9 \%$ & $38.5 \%$ & $23.1 \%$ & $6.7 \%$ & $13.3 \%$ & $53.3 \%$ & $26.7 \%$ \\
\hline 8 - Continence & $22.0 \%$ & $51.2 \%$ & $24.4 \%$ & $2.4 \%$ & $19.2 \%$ & $42.3 \%$ & $38.5 \%$ & $0.0 \%$ & $26.7 \%$ & $66.7 \%$ & $0.0 \%$ & $6.7 \%$ \\
\hline 9 - Openness & $29.3 \%$ & $39.0 \%$ & $24.4 \%$ & $7.3 \%$ & $19.2 \%$ & $50.0 \%$ & $23.1 \%$ & $7.7 \%$ & $46.7 \%$ & $20.0 \%$ & $26.7 \%$ & $6.7 \%$ \\
\hline 10 - Extroversion & $17.1 \%$ & $39.0 \%$ & $36.6 \%$ & $7.3 \%$ & $7.7 \%$ & $50.0 \%$ & $38.5 \%$ & $3.8 \%$ & $33.3 \%$ & $20.0 \%$ & $33.3 \%$ & $13.3 \%$ \\
\hline $\begin{array}{r}11-\begin{array}{r}\text { Emotional } \\
\text { instability }\end{array} \\
\end{array}$ & $12.2 \%$ & $29.3 \%$ & $48.8 \%$ & $9.8 \%$ & $11.5 \%$ & $38.5 \%$ & $50.0 \%$ & $0.0 \%$ & $13.3 \%$ & $13.3 \%$ & $46.7 \%$ & $26.7 \%$ \\
\hline 12 - Masculinity & $9.8 \%$ & $61.0 \%$ & $22.0 \%$ & $7.3 \%$ & $11.5 \%$ & $53.8 \%$ & $26.9 \%$ & $7.7 \%$ & $6.7 \%$ & $73.3 \%$ & $13.3 \%$ & $6.7 \%$ \\
\hline
\end{tabular}

Table 15 Traits of a mobber-percentage evaluation

\section{1 - Nervousness}

As the evaluation demonstrates the overwhelming majority of $64.3 \%$ perceive the mobber as a nervous person; $14.3 \%$ state that he is "almost always" nervous. An assessment of men and women correlates with their common evaluation, i. e. $63 \%$ of men and $66.7 \%$ of women describe the mobber as a predominantly nervous person.

\section{2 - Aggression}

When assessing the aggression all scale values have appeared. $69 \%$ of respondents assess the mobber as medium aggressive; $7.1 \%$ as almost always aggressive. $9.5 \%$ of the respondents characterize the mobber as a non-aggressive person. Most men (63\%) perceive the mobber as rather aggressive, 37\% as a rather non-aggressive person. Similarly most women (80\%) perceive the mobber as a rather aggressive person and only $20 \%$ as a rather non-aggressive person.

\section{3 - Depression}

The average evaluation of a mobber as a rather depressive person (50\%) and a rather non-depressive person $(50 \%)$ shows a very balanced assessment. More men $(55.6 \%)$ assess the mobber as a rather non-depressive, self-possessed person whereas, in contrast, more women $(60 \%)$ characterize the mobber as a depressive, discontented person.

\section{4 - Irritability}

Similar values as in the assessment of depression occurred in the assessment of irritability. The average values were balanced again: $50 \%$ of the respondents assess the aggressor as a rather irritable and $50 \%$ as a calm person. More men $(55.6 \%)$ assess the aggressor as a rather calm person whereas more women $(60 \%)$ characterize the aggressor as an irritable, slightly frustrated person. 


\section{Acta Technologica Dubnicae \\ volume 2, 2012, issue 1}

\section{5 - Sociability}

The majority (58.5\%) label the mobber as sociable and lively and $41.5 \%$ as rather antisocial and restrained. The assessments of men and women were similar in average values; majority of men $(61.5 \%)$ and majority of women $(53.3 \%)$ assess the aggressor as rather sociable and $38.5 \%$ of men and $46.7 \%$ of women assess the mobber as a rather antisocial and restrained person.

\section{6 - Gentleness}

Most respondents (63.4\%) perceive mobbers as calm, quiet and well-minded people, of which 9.8\% almost always think so. $36.6 \%$ assess the mobber as being irritable and hesitant. $69.2 \%$ of men characterize mobbers as rather gentle and $30.8 \%$ as rather irritable. Similarly, 53.3\% of women describe the aggressor as a gentle person and $46.7 \%$ as an irritable person.

\section{7 - Dominance}

In this case, $68.3 \%$ of the respondents describe the mobber as rather submissive, moderate and $31.7 \%$ as rather dominant. Most men $(61.5 \%)$ consider the person to be rather submissive and moderate; $38.5 \%$ of respondents view the person as rather dominant. Most women $(80 \%)$, similarly to men, assess the mobber as rather moderate and $20 \%$ as rather dominant.

\section{8 - Continence}

The majority of respondents (73.2\%) view the mobber as rather restrained and tensed and $26.8 \%$ describe the mobber as spontaneous and sociable. Assessment of men and women correlates with the summary evaluation, in which $61.5 \%$ of men and as many as $93.3 \%$ women assess the mobber as restrained and tensed and $38.5 \%$ of men and $6.7 \%$ of women assess the mobber as spontaneous and sociable.

\section{9 - Openness}

The assessment indicates that the mobber is rather open and critical. In the joint average assessment, most respondents $(68.3 \%$ ) view the mobber as above and $31.7 \%$ consider the person as withdrawn and uncritical. This joint assessment is identical with the assessment of most men $(69.2 \%)$ and most women $(66.7 \%)$.

\section{0 - Extroversion}

In this case, the assessments were in middle values. Most respondents $(56.1 \%)$ perceive the mobber as rather extrovert and social; of which $7.3 \%$ as almost always think so. $43.9 \%$ of the respondents assess the mobber as rather introvert. Similar percentage occurred with most men $(57.7 \%)$ and with most women $(53.3 \%)$ who describe the aggressor as rather extrovert, open and sociable and $42.3 \%$ of men and $46.7 \%$ of women describe the mobber as introvert and withdrawn.

\section{1 - Emotional instability}

In assessing the emotional instability the respondents favour the opinion that mobber is emotionally stable. $58.5 \%$ of the respondents assess the aggressor as rather emotionally stable and $41.5 \%$ consider the mobber as rather emotionally instable. Men's assessment is closer to the joint assessment, in which $50 \%$ indicates emotional stability and 50\% rather instability. These numbers are higher with women, as many as $73.3 \%$ of them describe the mobber as emotionally stable and $26.7 \%$ as rather emotionally hypersensitive and instable.

\section{2 - Masculinity}

All respondents agree that a mobber has typical male traits. In the joint assessment, $70.7 \%$ of the respondents assess the mobber as confident, creative and responsive and $29.3 \%$ characterize the mobber as rather typically feminine. In this case, the men's and women's assessments are identical with the joint assessment, in which most men (65.4\%) as well as most women (80\%) describe the aggressor by typically male characteristics. 


\section{Acta Technologica Dubnicae \\ volume 2, 2012, issue 1}

\section{Conclusions}

Out of the total of 150 distributed questionnaires 127 were completed; 85 were completed by men $(67 \%)$ and 42 by women (33\%). The average age of the participants was 44 years; average age of men was 43 years and average age of women was 45 years. Most respondents (63\%) are secondary school graduates with GRE test indicating that the companies are trying to employ qualified employers. The most numerous group consisted of ordinary employees (85\%), in which $14 \%$ of the respondents work as executives. The questionnaire evaluation shows that 18 respondents $(14 \%)$ have never experienced mobbing and majority of respondents $109(86 \%)$ have experienced some negative acts from time to time. Despite the reduction in mobbing occurrence and positive survey results, mobbing is present in the companies even nowadays. Interestingly, however, none of the respondents was mobbed regularly, i.e. daily, which is a very positive indication.

The third task was to indentify the position in the company of the people who were mobbed. Most of the 14 victims were ordinary employees (12) and 2 were in senior management group in last 6 months. One of the tasks was to determine to what extent the experience with mobbing is an individual or a group experience. For both, men and women, an individual experience with mobbing prevails; in 11\% of men a new form of mobbing occurred - staffing, in which subordinates attack the superior.

Next task, the fifth one, was to analyse the occurrence of negative acts and their frequency. Out of the total 29 negative acts, the respondents indicate that they have never met with negative acts $-71.9 \%$, $23.9 \%$ have sometimes experienced negative acts, $2.9 \%$ have experienced negative acts monthly, $1 \%$ have experienced negative acts weekly and $0.4 \%$ have been experiencing some of the negative acts daily. Out of the total 27 respondents, 14 respondents (11\%) perceive negative acts as mobbing: $6 \%$ rarely, $5 \%$ sometimes and $1 \%$ monthly. $89 \%$ respondents do not perceive negative acts as mobbing due to their rare frequency. We conclude that the frequency of negative acts has decreased at all levels; verbal aggression (threats, putting-down, and insults) prevails among men; passive aggression in the form of indirect communication and critical remarks prevails among women.

In the sixth task we tried to create a profile of the mobber based on the results provided by the questionnaire in which the perpetrator of negative acts is rather psychosomatically disturbed, irritable, rather aggressive and depressive, less calm, more sociable, lively, well-minded, slightly dominant, rather tensed, open, critical, extrovert, emotionally stable with typical male characteristics.

Based on the comparison of the results provided by sub-tasks, it can be concluded that mobbing is on a slight decline in this company which means that even the slightest indication of an aggressive act in a workplace should be paid attention to and should be suppressed. It is necessary to note that the assessment based on this survey cannot be considered as completely accurate and authoritative due to the assumption that the respondents have provided us with socially preferred answers caused by their fear of losing the job.

Based on the survey results, we propose the following:

- to develop a clear and written ethical code of the company in which it shall be clearly defined what is meant by aggression at the workplace;

- to provide clear examples of undesirable behavior;

- to specify consequences for threat or violent act;

- to encourage reporting of aggressive incidents;

- to determine how and to whom the incidents are to be recorded;

- to provide protection for the employee who reported such an incident in order to prevent the retaliation;

- to establish detailed investigation of these incidents;

- to solve conflicts as soon as they arise and openly communicate about them; 


\section{Acta Technologica Dubnicae \\ volume 2, 2012, issue 1}

- to apply "ethics programme" for employees in the area of violence prevention in the workplace, which shall include notifications based on the employment relations, and which will specify potential conflict of interests;

- to reduce input of monotonous and repetitive work;

- to develop management style and prevent vague specification of functions and tasks;

- to distribute organizational standards and values to all levels of the organization effectively, for instance, through staff manuals, information meetings and newsletters;

- to provide a clear definition and description of tasks in the organization, e.g. criteria and rules for promotion and reward system;

- to improve responsibility of management and their competencies and conflict-solving skills and communication skills;

- to include establishment of positive atmosphere in the workplace into the strategic objectives of the company, for instance, by organizing informal meetings focused on teambuilding, communication improvement and socializing in informal situations;

- to encourage appropriate workplace culture, which shall include the commitment of top management to employees' well-being, emphasis on the safety at work and dialogue between management and labour regarding the decisions about the workplace.

The introduction of these systems implicates changes regarding the personnel and their work. The implementation of the proposed activities is not easy; the effort to create an appropriate working climate is like a never-ending story but its constant nourishing, improvement and evaluation lead to a business success. It all depends only on the enterprise itself, whether and if it implements these proposals and profits from them along with its employees. The consequences may vary; they may endanger mental and physical health of employees and stability of the organization. The mobbed person may be forced to leave the company and the company, where mobbing occurred, may easily lose its key employees. Therefore it is important to monitor the occurrence of negative acts and fight mobbing in its inception. Lessons from other countries should warn us. Several countries have already implemented or are preparing to implement legislative amendments on the negative acts in order to make these acts illegal and provide protection to potential victims but also to sustain healthy and efficient operation of the companies and entire economies. It should be noted that prevention and education are the greatest opportunities to eliminate the negative behaviour in the bud. It just takes to pay more attention to one's surroundings, to be more tolerant, to understand that others are also facing some problems and to give up egoism and own welfare and express your own opinion about this issue and actions associated with it.

\section{References}

BENEŠOVSKÁ, J.: Mobbing - ked’ práca bolí na duši. In: Moja psychológia, vol. 1, 2009, no. 10, p. 56-59.

GOSSÁNYI, V.: Problémy schované pod strachom. In: Hospodárske noviny, 2007, no. 43, p. 21.

HIRIGOYENOVÁ, M. F.: Psychické týranie. Bratislava: Sofa, 2001, 267 p.

HORVÁTH, G.: Mobbing - šikanovanie na pracovisku. In: Rodina a škola, vol. 49, 2001, no. 9, p. 11.

HUBEROVÁ, B.: Psychický teror na pracovisku. Martin: Neografia, 1995, 143 p.

KRATZ, H. J.: Mobbing - jak ho rozpoznat a jak mu čelit. Praha: Managment Press, 2005, 131 p.

MERG, K. - KNŐDEL, T.: Jak prežit v práci. Brno: Computer press, 2007, 145 p.

PRAŠKKO, J. - PRAŠKOVÁ, H.: Asertivitou proti stresu. Praha: Grada, 2007, 277 p.

PROVAZNÍK, V.: Psychologie pro ekonomy a manažery. Praha: Grada, 2002.

SVOBODOVÁ, L.: Nenechte se šikanovat kolegou. Praha: Grada, 2008, 108 p. 